\title{
CONCEPTUAL REFLECTIONS ABOUT ORGANIZATIONAL AND PROFESSIONAL COMMITMENT IN THE HEALTH SECTOR
}

\author{
Eliana Ofelia LLapa-Rodríguez ${ }^{1}$ \\ Maria Auxiliadora Trevizan ${ }^{2}$ \\ Gilberto Tadeu Shinyashiki ${ }^{3}$
}

LLapa-Rodríguez EO, Trevizan MA, Shinyashiki GT. Conceptual reflections about organizational and professional commitment in the health sector. Rev Latino-am Enfermagem 2008 maio-junho; 16(3):484-8.

In the daily exercise of their functions, health professionals face a duality of systems, that is, the professional system and the organizational system, each of which has its own distinct values, principles and expectations. The authors aim to present organizational and professional commitment concepts and their relations in the context of the health sector. They consider that organizational and professional commitment are not incompatible, but can be reconciled in the organizational dynamics, and alert about the development of affective commitment in workers, due to the positive consequences for the organization and the profession.

DESCRIPTORS: health manpower; organization and administration

\section{REFLEXIÓN CONCEPTUAL SOBRE COMPROMISO ORGANIZACIONAL Y PROFESIONAL EN EL SECTOR SALUD}

Dentro de su cotidiano, los profesionales de salud al ejecutar sus funciones enfrentan una dualidad de sistemas, es decir, el sistema profesional y el sistema organizacional, cada uno con sus valores, principios $y$ expectativas distintos. El objetivo de los autores es presentar conceptos de compromiso organizacional y profesional y sus relaciones en el contexto del área de la salud. Consideran, que el compromiso organizacional y profesional no son incompatibles siendo, por tanto, conciliables dentro de la dinámica organizacional. Alertan para el desenvolvimiento de compromiso afectivo en trabajadores por las consecuencias positivas en la organización y profesión.

DESCRIPTORES: recursos humanos en salud; organización y administración

\section{REFLEXÕES CONCEITUAIS SOBRE COMPROMETIMENTO ORGANIZACIONAL E PROFISSIONAL NO SETOR SAÚDE}

Os profissionais de saúde, no cotidiano, ao exercerem suas funções enfrentam dualidade de sistemas, ou seja, o sistema profissional e o sistema organizacional, cada qual com seus valores, princípios e expectativas distintos. O objetivo dos autores é apresentar conceitos de comprometimento organizacional e profissional e suas relações no contexto do setor saúde. Considera-se que o comprometimento organizacional e o profissional não são incompatíveis, sendo, portanto, conciliáveis na dinâmica organizacional. Alerta-se, também, para o desenvolvimento do comprometimento afetivo dos trabalhadores pelas conseqüências positivas para a organização e profissão.

DESCRITORES: recursos humanos em saúde; organização e administração

${ }^{1}$ RN, Doctoral student in Nursing, e-mail: eliestom@eerp.usp.br; ${ }^{2}$ RN, Full Professor, e-mail: trevizan@eerp.usp.br. University of São Paulo at Ribeirão Preto College of Nursing, WHO Collaborating Centre for Nursing Research Development, Brazil; ${ }^{3}$ Psychologist, Ph.D., Faculty, University of São Paulo at Ribeirão Preto School of Economics, Business Administration and Accountancy, Brazil, e-mail: gtshinya@usp.br 


\section{INTRODUCTION}

The role of workers in the health sector has been marked by rationality in the development of their actions, demanding that these professionals comply with norms and regulations. When they exert management functions, they adopt classical management principles. This impairs their commitment with professional values, as their attention becomes focused on organizational expectations.

Conflicts due to organizational and professional commitment have affected the conduct of health professionals. This situation needs to be changed and these professionals are seeking to modify their practice in the organizational context. In general, we can say that, in health organizations, these different professionals' change has occurred slowly, configuring a moment of transition from conventional to contemporary management.

This way, this study aims to present organizational and professional commitment concepts and their relations with the health sector.

\section{CONCEPTUALIZING ORGANIZATIONAL AND PROFESSIONAL COMMITMENT}

Organizational psychology has shown, over time, the importance of commitment in the organization/worker relation. In this area, efforts have focused on a clear and precise definition of commitment.

It has been difficult to reach a general consensus on a definition of commitment that would allow for an understanding of the construct. Many definitions are found in the literature and methods of measurement developed and used in research on this theme, described next.

The concept of commitment was defined in two ways in the 1960s: (a) cosmopolitan integration, degree to which the individual is active and feels part of several levels of an organization, especially at higher levels, (b) organizational introjection, degree to which the individual incorporates a variety of organizational qualities and approved values ${ }^{(1)}$.

Other authors ${ }^{(2)}$ consider commitment a mechanism that produces solid behaviors, favors engagement of people in line with activities they elected themselves to achieve their goals. Commitment is understood as the totality of normative pressures internalized to act on the path that converges to organizational interests.

Besides the diversity of concepts, some articles $^{(4-6)}$ have questioned researchers' explanations about organizational commitment, which reflects the lack of precision and redundancy of concepts, although this construct has been extensively defined, measured and examined ${ }^{(5)}$.

Regarding definitions on commitment at work, only those aspects related to the organizational and professional environments will be highlighted (7): "...the relative strength of identification and involvement of an individual in a specific organization"; "...the sum of normative pressures used for an individual to act towards organizational objectives and interests"; "...the psychological connection of a person with an organization reflects the degree to which (s)he internalizes and adopts characteristics or perspectives of the organization"; "...a psychological state that connects the individual to the organization"; "...an attitude of a person in relation to his(er) profession or vocation"; "...the motivation to work on the vocation chosen".

In Brazil, a study on the state-of-art of commitment ${ }^{(8)}$ presented advancements and the importance of the topic. The authors stress the work of Bastos, presented at the $16^{\text {st }}$ Meeting of the National Association of Post-Graduate Programs and Research in Business Administration (EnANPAD), as a study with great repercussion among researchers in the area. Bastos' advancements allowed for the construction of patterns of commitment ${ }^{(9)}$ : the doubly committed, those individuals committed with both career and organization; the doubly non-committed, those committed neither with the organization or profession; the unilaterally committed with the organization; and those unilaterally committed with the profession. These are patterns of great repercussion among Brazilian scholars in the area.

International researchers show the importance of the theme ${ }^{(10)}$, elaborating studies on multidimensional issues, considered more adequate to understand commitment ${ }^{(4)}$.

Another important issue is professional commitment. Thus, it is necessary to establish the difference between career, profession and occupation concepts, because these are used in the definition of professional commitment. Occupation/vocation "describe the mastering or establish a set of knowledge and abilities related to the production of goods or delivery of services". Profession refers to a set of 
characteristics that can vary from one occupation to another, that is, high involvement, feeling of identity, autonomy and high adherence to objectives and professional values. Career comprehends both occupations and professions and considers a sequence of jobs related to a certain field ${ }^{(9)}$.

Commitment with the profession ${ }^{(7)}$ "is an attitude of a person in relation to his(er) profession or vocation" and "...motivation to work on the vocation chosen".

In this sense, organizational commitment has been a theme of great interest in research on human behavior in organizations; professional commitment, on the other hand, is a new and expanding research line among researchers in the $\operatorname{area}^{(7,9-13)}$.

In the three-component model - affective, instrumental and normative - ${ }^{(14)}$, professional and organizational commitments refer, respectively, to the involvement of the individual with his/her profession and organization. An affectively committed individual is emotionally engaged with profession and organization; normatively committed feels obliged to remain in the profession and organization; and finally, instrumentally committed is the individual whose involvement is related or associated to costs of giving up profession and organization.

Thus, the profile of the affectively, instrumentally and normatively committed individual is that of a person who desires, needs and feels obliged to remain in the profession and organization.

There is evidence that involvement at work, organizational commitment and the worker's satisfaction are possibly related to commitment with the profession ${ }^{(11)}$. The author encourages the study and analysis of situational variables (financial motivation, adaptability, feedback process and autonomy) and individual variables (extra work) for a better understanding of the theme.

Thus, according to the definitions given, commitment summarizes feelings of involvement, loyalty and bonding, both to the organization and the profession.

\section{COMMITMENT AS A MULTIDIMENSIONAL VARIABLE}

The nature of commitment with the organization has been addressed through two lines, the attitudinal and the behavioral ${ }^{(5,7,14)}$, also called affective and instrumental ${ }^{(9)}$.

Attitudinal commitment refers to identification of the individuals with organizational goals and their efforts to work towards the organization's welfare. Behavioral commitment is considered an attributional benefit, related to gains associated to the maintenance of the individual in the organization ${ }^{(5,7,9,14)}$.

In view of the taxonomy of work attachment, the existence of multiple aspects is acknowledged and highlighted, which are able to create bonding in workers $^{(9)}$. Therefore, we can affirm there is not a single bond in the worker/employer relation. Since commitment is a multidimensional issue, it possesses several variables that influence and cause impact in one and/or in another dimension ${ }^{(9-10,15)}$.

The three-component model of commitment presents the relations existent between three types of commitment (affective, instrumental/continuous and normative) and variables considered as antecedent, correlate and consequent ${ }^{(14)}$, which markedly influence turnover, behavior at work, performance, absenteeism and workers' citizenship.

Meta-analysis on antecedent, correlate and consequent variables of organizational commitment appointed 26 variables classified as antecedent, highlighting personal characteristics, work characteristics, group/leader relation and organizational characteristics; eight variables as consequent, highlighting the group of variables related to performance at work; and 14 correlate variables, such as motivation and satisfaction at work ${ }^{(10)}$.

In a study of the relation between satisfaction and stress in health professionals who work in correctional institutions, the influence of salary and autonomy on professionals' satisfaction was identified. It was also verified that variables like organizational pressure, organizational support and organizational involvement are sources of stress for the subjects studied ${ }^{(16)}$.

Another model studied is the causal turnover model among hospital nurses ${ }^{(17)}$. Turnover is affected by four determinants: opportunity, satisfaction at work, intention of staying, and training. That is, the bigger the opportunity at work, satisfaction and training, the higher the chances of professionals staying at the institution, consequently reducing turnover at hospital units.

After the three-component commitment model was presented, the structure of four dimensions for professional commitment was elaborated, which is an expansion of the three-dimension-structure for organizational commitment. Based on previous studies, the author considers that the instrumental or continuous commitment should be put into operation in two separated dimensions: the commitment by 
accumulated costs and that associated to limited occupational alternatives. The author encourages the use of this new model in this line of research, integrating other issues (such as work, organization and occupation) and other bases (e.g. affective, normative, accumulated costs and limited alternatives) to enrich knowledge and its applicability in organizations.

As observed, the models above present similarities and differences regarding types and issues of commitment and antecedent, correlate and consequent variables.

\section{RELATIONS BETWEEN ORGANIZATIONAL AND PROFESSIONAL COMITTMENT}

The bonding developed between the individual and the organization is very important. Thus, institutions should consider new strategies regarding commitment to achieve organizational objectives.

Success or failure in the implementation of strategies will largely depend on the involvement of people and managers' leadership. In this sense, research on organizational and professional commitment seeks to reveal new issues and bases of these two constructs.

This way, organizational and professional commitment, treated as multidimensional constructs, are important when combined in the exploration of a single object of study ${ }^{(9)}$

Researchers in the area mention ${ }^{(18)}$ that the conciliation-conflict relation between organization/ profession can be mediated by the level at which the profession is compatible with personal vocation, as well as by the level at which the individual finds support for his(er) own professional realization.

Assertions were found ${ }^{(19)}$ which state that both high and low levels of commitment are detrimental for the individual and organization, and that moderate levels are the most adjustable ones, balancing satisfaction of individual and organizational needs.

The system of values adopted in institutions has a different focus on these aspects. The system of values of institutions training these professionals is based on professional autonomy and, especially, on the code of ethics established, in disagreement with the system of values of employment institutions, which is based on hierarchical authority, in the control, regulations and norms that establish basic rules for the transit of members inside institutions.
However, organizational and professional commitments are not necessarily incompatible ${ }^{(13)}$; conflicts would not exist between the two if professionals' expectations and objectives met those of the organizations they work for.

Researchers in the area consider that professional commitment can be more positive ${ }^{(9)}$, stressing that, because it possesses a specific set of tasks, it can trigger a high level of commitment and, thus, involve the individual with higher intensity to achieve the proposed objectives.

A classical classification of commitment ${ }^{(20)}$ identified cosmopolitan individuals as people with a low level of loyalty to the organization and high commitment to the profession, and localist individuals as people with high commitment to the organization and low level of commitment with the profession.

The taxonomy with four patterns states that the cosmopolitan - localist individual presents high commitment to the profession and high loyalty to the organization; the cosmopolitan demonstrates high level of commitment with the profession and low loyalty to the organization; the localist individual expresses high loyalty to the organization and low commitment with the profession; and those who are neither cosmopolitan nor localist present low commitment with both profession and organization ${ }^{(18)}$.

Four patterns of commitment were also found in nursing ${ }^{(21)}$, which are related with the situation of nurses' unemployment.

In summary, studies clarify the importance of studying organizational commitment to avoid turnover and intention of leaving the organization. We also agree with authors ${ }^{(10,13-14,18,22-23)}$ who consider that professional commitment can be a important construct in favoring paths that explain employees' conducts and attitudes in organizations.

Thus, the impact organizational and professional commitments have on health organizations is essential for the effective performance of professionals in the achievement of organizational objectives and goals.

Considering the context of workers in the health sector, "a call for immediate action is in course, able to respond to the crisis and to value, invest and empower to human resources in the health area. This movement requires large-scale participation and involvement in strategic planning and actions"(24). The effective interaction between the academy and health services guides teaching for the reality of professional actions in health organizations, permitting attitudes linked to principles of equity, care universality and integrality of actions ${ }^{(25)}$. 


\section{FINAL CONSIDERATIONS}

It is currently observed that organizations need to be efficient and effective to achieve institutional objectives and goals.

The good performance of work teams and the impact of results will largely depend on the competence and involvement of people in the organization and profession. The development of affective commitment should be favored and encouraged in individuals because of the positive consequences it can entail for the organization and the profession. Workers with affective commitment become a valuable and singular asset for the success of the organization.

\section{REFERENCES}

1. Goulder H P. Dimensions of organizational commitment. Adm Sci Q 1960; 4: 468-90.

2. Becker H S. Notes on the concept of commitment. Am J Sociol 1960; 66(1): 32-40.

3. Wiener Y. Commitment in organizations : a normative view. Acad Manage Rev 1982; 7(3):418-28.

4. Meyer JP, Allen NJ."Testing the Side-bet theory" of Organizational Commitmet: Some methodological Considerations. Appl Psychol 1984; 69: 372-8.

5. Reichers A. A review and reconceptualization of organizational commitment. Acad Manage Rev 1985; 10(3): 465-76.

6. Van Scotter JR. Relationships of task performance and contextual performance with turnover, job satisfaction an affective commitment. Hum Resource Manage Rev 2000; 10(1): 79-95.

7.Scheible ACF. Comprometimento no trabalho : um estudo de caso de suas relações com desempenho e práticas de gestão. [dissertação]. Salvador (BA): Escola de administração/UFB; 2004.

8. Medeiros CAF, Alburquerque LG, Siqueira M, Marques GM. Comprometimento Organizacional: o Estado da Arte da Pesquisa no Brasil. In: EnANPAD - Encontro Nacional dos Programas de Pós-Graduação em Administração 2002, Setembro 22-25; Salvador: Bahia; 2002.

9. Bastos AVB. Comprometimento no trabalho : a estrutura dos vínculos do trabalhador com a organização, a carreira e o sindicato. [Dissertação]. Brasília (DF): Instituto de Psicologia/ UFB; 1994

10. Mathieu JE, Zajac DM. A review and Meta-Analysis of the Antecedents, Correlates and Consequences of Organizational commitment. Psychol Bull 1990 September; 180(2): 171-94 11. Goulet LR, Singh P. Career commitment : a reexamination and an extension. Vocat Behav 2002; 61:73-91.

12. Blau J. Testing for a four- dimensional structure of
Finally, we conclude that organizational commitment and professional commitment are not incompatible, although the existence of conflicts is caused by divergence between the two in relation to goals and expectations. Thus, it is up to health education and health care organizations to consider the situation and benefits that can be generated when individuals are committed to the work, causing a positive impact on both internal and external clients.

In our understanding, organizational and professional commitments are essential for the development of these attitudes.

occupational commitment. Occup Org Psychol 2003; 76:469-88

13. Wallace JE. Professional and organizational commitment : compatible or incompatible. Vocat Behav 1993;42:333-49.

14. Meyer JP, Allen NJ, Smith CA. Commitment to organizations and occupations : extension and test of a threecomponents conceptualization. Appl Psychol 1993; 78(4):538-51.

15. Meyer JP, Stanley DJ, Herscovitch L, Topolnytsky L. Affective, continuance and normative commitment to the organization : a meta-analysis of antecedents, correlates and consequences. Vocat Behav 2002; 61: 20-52.

16. Flanagan NA, Flanagant J. An analysis of the relationship between job satisfaction and job stress in correctional nurses. Res Health 2002;25:282-94.

17. Price JL, Mueller CW. A causal modelof turnover for nurses. Acad Manage J 1981; 24(3):543-65.

18. Bastos AVB. Padrões de comprometimento com a profissão e a organização: o impacto de fatores pessoais e da natureza do trabalho. Rev Adm outubro/dezembro 2000; 35(4): 127.

19. Randall D. Commitment and the organization : the organization man revisited. Acad Manag Rev 1987; $12(3): 460-71$

20. Gouldner, A.W. Cosmopolitans and locals: towardan analysis of latent social rotes-I. Admin Sci Q 1957; 2: 281-306.

21. Costa TM. Comprometimento da enfermeira com a organização hospitalar e com a carreira : um estudo decaso em uma organização hospitalar. [Dissertação]. Salvador (BA): Escola de Enfermagem /UFB; 1998.

22. Blau G. On assesingthe construct validity of two dimensional constructs occupational commitment and ocupational entrenchment. Hum Resource Manage Rev 2001; 11: 279-98.

23. Arford $\mathrm{P}$, Zone-Smith L. Organizational commitment to profesional practice model. Nurs Admin 2005; 35(10): 46772.

24. Mendes IAC, Marziale MHP. Década de Recursos Humanos em saúde: 2006-2015. Rev Latino-am Enfermagem janeiro-fevereiro 2006; 14(1):1-2.

25. Mendes IAC, Marziale MHP. Sistema de saúde em busca de excelência: os recursos humanos em foco. Rev Latino-am Enfermagen maio-junho 2006; 14(3): 303-4. 